\title{
Impact of evapotranspiration on discharge in small catchments
}

\author{
Š́rka Dvoř́áková ${ }^{*}$, Pavel Kováŕ ${ }^{2}$, Josef Zeman ${ }^{3}$ \\ ${ }^{1}$ Faculty of Engineering, Department of Mathematics, Czech University of Life Sciences, (CULS Prague), Kamycka 129, 16521 Prague 6, \\ Czech Republic. \\ ${ }^{2}$ Faculty of Environmental Sciences, Department of Land Use and Improvement, CULS Prague, Czech Republic. \\ ${ }^{3}$ Faculty of Engineering, Department of Physics, CULS Prague, Czech Republic. \\ *Corresponding author. Tel.: +42022438 3240. E-mail: dvorakovas@tf.czu.cz
}

\begin{abstract}
We apply the Linear Storage Model (LSM) to simulate the influence of the evapotranspiration on discharges. High resolution discharge data from two small catchments in the Czech Republic, the Teply Brook and the Starosuchdolsky Brook catchment are used. The results show the runoff process is simpler in a deeper valley of the Starosuchdolsky catchment where the soil zone is deeper and the valley bottom recharges runoff even during very dry periods. Two-soil zone model is adequate to simulate the diurnal runoff variability. Three-soil zone model is needed in the Teply Brook catchment due to the absence of water transport in the most-upper soil zone. Time delays between minimum and maximum discharge during the day reach up to about 20 hours. Evapotranspiration and hydraulic resistances are as high as $14 \%$ of catchment daily runoff in the urbanized Starosuchdolsky Brook catchment and $25 \%$ of catchment daily runoff in the forested, less impacted Teply Brook catchment.
\end{abstract}

Keywords: Catchment water depletion; Diurnal streamflow variability; Evapotranspiration; Linear Storage Model (LSM).

\section{INTRODUCTION}

Because discharge fluctuations quantitatively reflect rainfall inputs to the catchment, it is natural to ask whether they also reflect evapotranspiration losses from the catchment (Kirchner, 2009). Hydrologists have developed several strategies for using discharge measurements during streamflow recession to study evapotranspiration rates (Bond et al., 2002; Burt et al., 2010; Dvořáková and Zeman, 2010a, 2010b; Szilagyi et al., 2007). In a catchment, dynamic systems have comparable but opposite effects on catchment storage and thus on streamflow (Kirchner, 2009). High-resolution measurement of fluctuating discharges can be used to study temporal patterns of catchment-scale evapotranspiration. A smoothly harmonic diurnal or seasonal discharge fluctuation is caused mostly by evapotranspiration of riparian vegetation. This process can be described simply by the sine curves or more sophisticatedly by the Fourier series or other harmonic functions (Dvořákova et al., 2012; Kovář et al., 2014).

The interaction between vegetation and the hypodermic zone, or shallow groundwater, is an important part of ecosystem dynamics in a riparian zone. Where the catchment area supplies alluvial groundwater, there can be a significant reduction in the volume of water actually reaching the stream, which was often described earlier (e.g., Troxell, 1936). When analysing the hydrological response during the summer drought of 1976, Burt (1979) noted that observations of short-term step discharges showed a clear diurnal fluctuation. He characterised this phenomenon as a response to intense evapotranspiration during the day, and a resumption of downslope water movement at night. Bren (1997) studied the effect of the removal of slope vegetation on the diurnal variations of a small mountain stream in Australia. He concluded that the amplitude of the variation diminishes in time and is insensitive to changes in slope hydrology. Bond et al. (2002) described the time lag between base flow and actual flow and used it to estimate the zone, or area of riparian vegetation that influenced the daily streamflow patterns. Loheide et al. (2005) and Winsemius et al. (2006) investi- gated evapotranspirative consumption of groundwater using the concept of readily available specific yield based on diurnal fluctuations in discharge. They described the method of specific yield determination based on soil texture and the master recession curve. When Fenicia et al. (2006) published the results of their research, important progress was made in understanding the dynamics of unsaturated and saturated zones, and also evapotranspirative consumption by phreatophytes, taking into account diurnal water table fluctuations. The results triggered discussion about the general use of a linear groundwater reservoir in hydrological modelling. There are also papers available that provide results at catchment scales where almost no impact of riparian vegetation during low flows can be observed. A comparison of two catchments of this kind was made in Tanzania (Mul et al., 2007), one covering less than $1 \mathrm{~km}^{2}$, the other covering approximately $25 \mathrm{~km}^{2}$. At a larger scale, the influence of this hydrological process is no longer visible.

The objective of our work is to analyse the impact of evapotranspiration from riparian vegetation on runoff in two small catchments, the Teply Brook and the Starosuchdolsky Brook catchments that have a different geomorphology.

\section{METHODOLOGY \\ Simulation of evapotranspiration by the Linear Storage Model LSM}

The LSM model is based on approximation of catchment runoff during rainless period by an equation representing depletion of the linear storage (Fig. 1). The model describes the behaviour of catchment areas by using the idea of two or three soil zones that form vertically interconnected water storages. Flow of water between the storages is given by the difference in their saturation. Contribution of individual zones into the channel is proportional to the immediate amount of free water in the zones. Water is withdrawn by evapotranspiration from the upper-, middle- and lower- soil-zones and evapotranspiration is considered as a diurnally periodical process. 
Two- and three-zone alternative models are described by equations (1) and (2) respectively:

$$
\begin{aligned}
& Q_{S}(t)=A \cdot e^{-\frac{t}{\tau_{1}}}+B \cdot e^{-\frac{t}{\tau_{2}}}+D \sin (\omega t+\psi) \\
& Q_{T}(t)=A \cdot e^{-\frac{t}{\tau_{1}}}+B \cdot e^{-\frac{t}{\tau_{2}}}+C \cdot e^{-\frac{t}{\tau_{3}}}+D \sin (\omega t+\psi)
\end{aligned}
$$

where, subscripts ${ }_{S}$ and ${ }_{T}$ identify the names $\underline{\text { Starosuchdolsky }}$ and Teply Brook catchments, then $Q_{S}(t)$ and $Q_{T}(t)$ are catchment discharges $\left(1 \cdot \mathrm{s}^{-1}\right) ; A, B, C$ are initial relative water storages in the upper $(A)$, middle $(B)$ and lower $(C)$ soil-zone of the catchment; $\tau_{1}, \tau_{2}, \tau_{3}$ are half-term duration to be achieved on $1 / \mathrm{e}$, with $\mathrm{e}-$ the Euler constant for water storage in zones $A, B, C$ (day). Practically it is also the exhaustion time for water storage in each soilzone; $D$ is actual daily evapotranspiration which reduced catchment discharge $\left.1 \cdot \mathrm{s}^{-1}\right) ; \omega t$ is duration of the time lapse for a one-day period ( $\omega=24 \mathrm{~h}, 1$ day); $\psi$ is time delay between the daily maximum and minimum streamflow (hours)

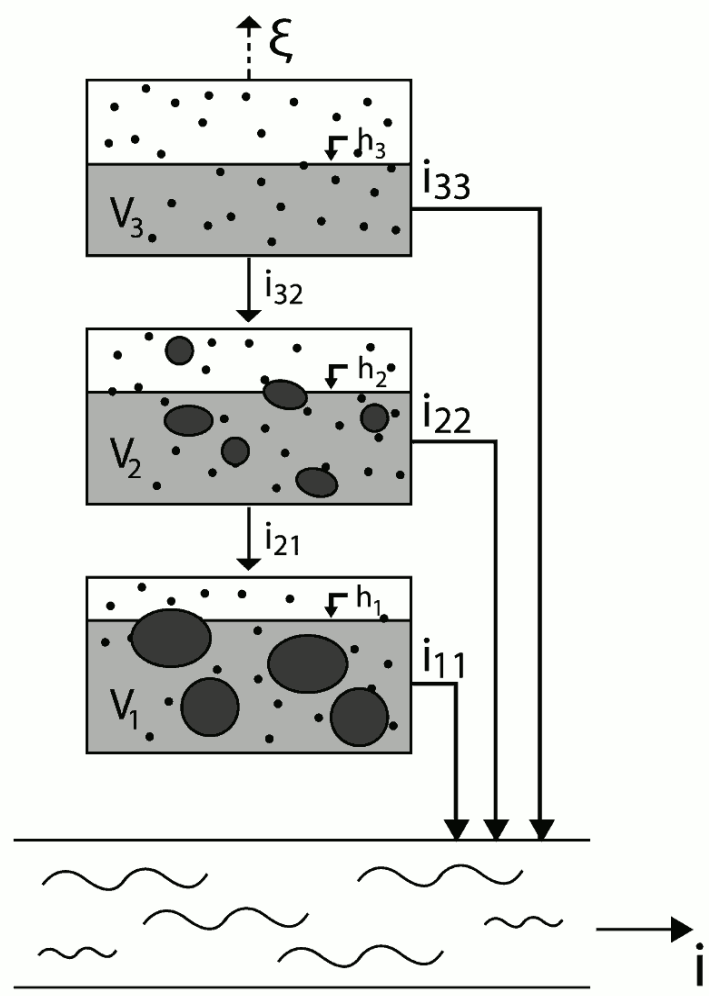

Fig. 1. Scheme of the LSM model. $h_{1}$ is relative groundwater level $(-) ; h_{2}$ is relative subsurface soil-zone water level $(-) ; h_{3}$ is relative most-upper (surface) soil-zone water level $(-) ; \mathrm{V}_{1}$ is relative volume (porosity) of groundwater reservoir (-); $\mathrm{V}_{2}$ is relative volume (capacity) of subsurface soil-water reservoir $(-)$; $\mathrm{V}_{3}$ is relative volume (capacity) of most-upper (surface) water reservoir $(-)$; i is discharges (measured value at the catchment's outlet profile) $\left(1 \cdot \mathrm{s}^{-1}\right) ; \mathrm{i}_{21}$ is flow from groundwater to subsurface soil-zone water $\left(1 \cdot \mathrm{s}^{-1}\right) ; \mathrm{i}_{32}$ is flow from subsurface soil-zone water to upper-most (surface) soil-zone water $\left(1 \cdot \mathrm{s}^{-1}\right) ; \quad \zeta$ is evapotranspiration coefficient $(-) ; i_{11}$ is groundwater contribution to streamflow $\left(1 \cdot \mathrm{s}^{-1}\right) ; \mathrm{i}_{22}$ is subsurface (hypodermic) water contribution to streamflow $\left(1 \cdot \mathrm{s}^{-1}\right) ; \mathrm{i}_{33}$ is surface water contribution to streamflow $\left(1 \cdot \mathrm{s}^{-1}\right)$.

The values of $A, B, C, D, \tau_{i}$ and $\psi$ resulting in the best approximation of measured discharges are determined through calibration. Calibration is done, ab initio, i.e. the extra calibration is carried out for every day. Calibrated values are later presented in annual graphs. The least squares method is used to evaluate the performance of the simulation. Coefficients $A$ to $C$ provide information on the soil zones saturation and total capacity. The values $D$ and $\psi$ characterizing actual daily evapotranspiration and time delay between daily maximum and minimum streamflow are of special focus in this study. It is assumed that the evapotranspiration is characterized by the sine function; it is independent on meteorological conditions and dependent on available water in soil-zone storages. It is assumed that the yearly periodical change of $\tau_{l}$ characterizes the exhaustion time for zone A.

\section{Studied area and data}

Two small catchments (the Teply Brook, the Starosuchdolsky Brook) in the Czech Republic are studied. Catchment characteristics are given in Figs. 2 and 3 and in Table 1. The Teply Brook catchment is mostly forested. The lower part of its valley is covered mainly by deciduous forest. The oakhornbeam forest dominates in the upper part of the catchment and the alluvium is overgrown with the ash-alder forest. In general, the composition of vegetation is not natural. It is represented by three levels and was influenced by man-made activities. The most common tree level species are Quercus robur and Q. petrea, Acer campestre, Larix decidua, Robinia pseudoaccacia and close to the stream Alnus glutinosa and Fraxinus excelsior. The scrub level is dominated by Sambucus nigra, Corylus avellana and Crataegus sp.; the herb level is on the catchment bottom dominated by nitrophilous species, such as Urtica dioica, Aegopodium podagraria, Poa palustris etc. According to long-term phenological observations the vegetation season starts in the middle of April and ends in the middle of November (Larcher, 1988; Roznovsky et al., 2006).

The prevailing land use in the Starosuchdolsky Brook catchment is represented by arable land $(50 \%$ of catchment area) and urbanised areas (38\%). Forested area is a mixture of semi-naturals. The downstream part of the catchment is environmentally protected in its riparian belts by a valuable canopy. These river belts, situated on both sides of the Starosuchdolsky Brook contain typical local forest species represented by Alnus glutinosa, Fraxinus excelsior, Quercus robur, and rarely Carpinus betulus.

Diurnal discharge fluctuation during a hot and dry summer period occurs in both studied catchments. Soil moisture measurements show that the main difference in runoff depletion between the two catchments is that the upper-most soil-zone of the Teply Brook catchment is sometimes completely exhausted from water. Thus, this zone does not contribute to the streamflow. The upper-most soil-zone of the Starosuchdolsky Brook catchment is always partially saturated owing to its deep valley morphology. Therefore, it permanently contributes to the streamflow.

The Starosuchdolsky Brook catchment is described as a twozone system (eq. (1)), while the Teply Brook catchment is represented by the three-zone system (eq. (2)). High time resolution discharge data in the Teply Brook catchment was measured from 2004 to 2007. The Starosuchdolsky Brook catchment has been monitored since 2011. The available data is used to calibrate the LSM model. The discharge data is obtained from the water table data measured every two seconds at the outlet of the catchments using the V-notched (Thomson) weir equipped with the Vegawell 71 submersible water level gauge. The gauge measures water pressure with high resolution sensitivity. 
Table 1. The characteristics of the Teply Brook and the Starosuchdolsky Brook catchment.

\begin{tabular}{|c|c|c|c|c|}
\hline \multicolumn{3}{|c|}{ Physiographical factors } & \multirow{2}{*}{$\begin{array}{c}\text { Teply Brod } \\
1.56\end{array}$} & \multirow{2}{*}{$\begin{array}{c}\text { Starosuchdolsky Brod } \\
2.95\end{array}$} \\
\hline A & Catchment area & $\mathrm{km}^{2}$ & & \\
\hline $\mathrm{L}_{\text {th }}$ & Length of thalweg & $\mathrm{km}$ & 1.41 & 3.7 \\
\hline $\mathrm{L}_{\mathrm{b}}$ & Length of brook & $\mathrm{km}$ & 1.1 & 0.58 \\
\hline$P$ & Length of water divide & $\mathrm{km}$ & 5.13 & 9.1 \\
\hline $\mathrm{I}_{\mathrm{b}}$ & Average slope of brook & $\%$ & 13.0 & 5.4 \\
\hline $\mathrm{I}_{\mathrm{S}}$ & Average catchment slope & $\%$ & 15.1 & 20 \\
\hline $\mathrm{H}_{\max }$ & Maximum catchment elevation & m a.s.l. & 595 & 335 \\
\hline $\mathrm{H}_{\min .}$ & Minimum catchment elevation (outlet) & m a.s.l. & 417 & 211 \\
\hline \multirow[t]{4}{*}{$\mathrm{R}_{\mathrm{d}}$} & River network density & - & 2.4 & 0.33 \\
\hline & Annual precipitation & $\mathrm{mm}$ & $650-750$ & $350-400$ \\
\hline & Annual runoff & $\mathrm{mm}$ & $220-250$ & $120-140$ \\
\hline & Annual average temperature & ${ }^{\circ} \mathrm{C}$ & 7 & 8.8 \\
\hline \multicolumn{5}{|c|}{ Land use categories } \\
\hline & Arable land & $\%$ & 12.8 & 50.2 \\
\hline & Forest & $\%$ & 80.0 & 3.5 \\
\hline & Urbanized area & $\%$ & 0 & 37.9 \\
\hline & Permanent grassland/greenery & $\%$ & 7.2 & 8.4 \\
\hline
\end{tabular}
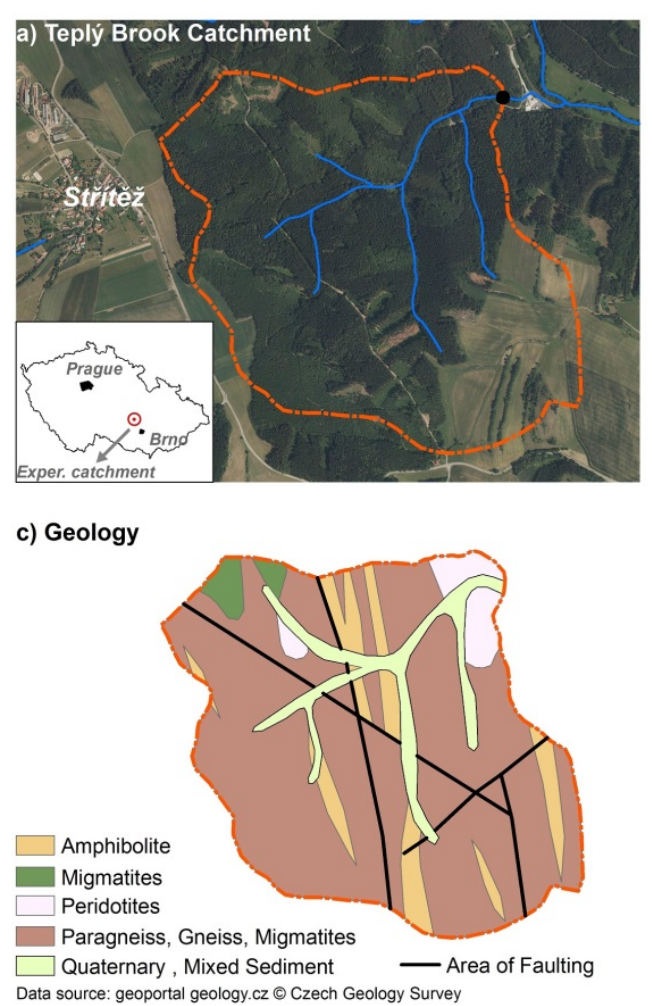

e) Soil Types

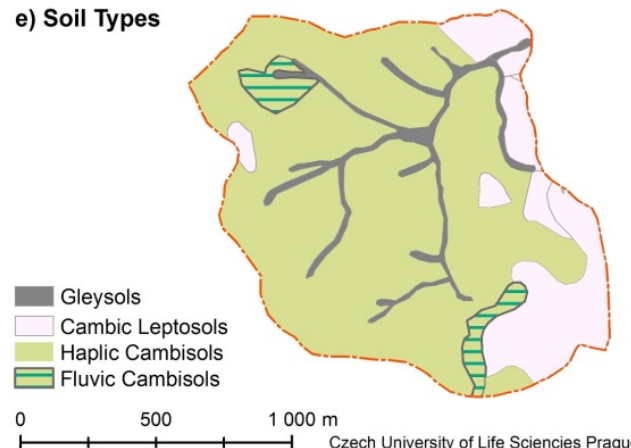

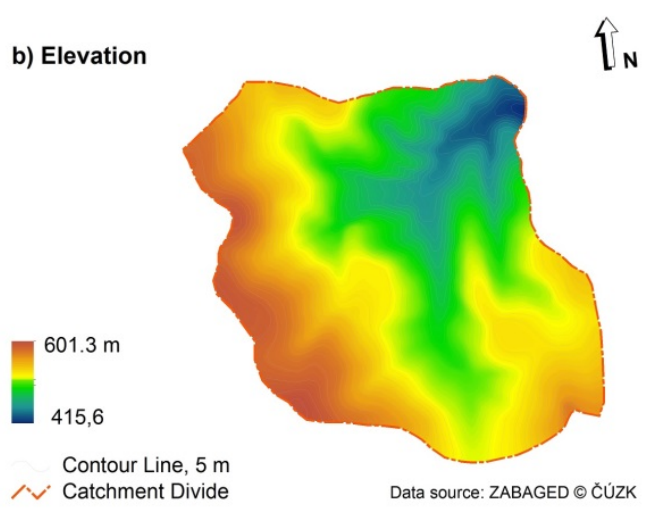

d) Slope

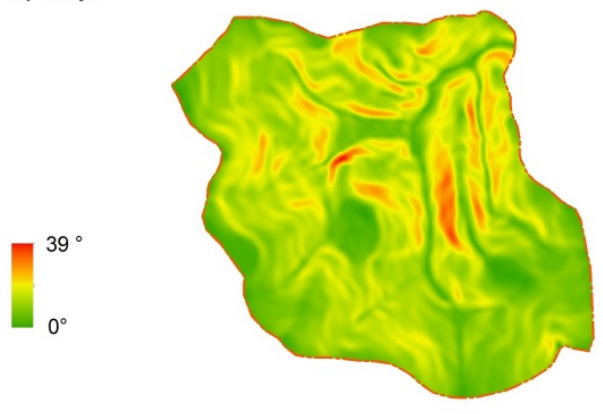

f) Land Use

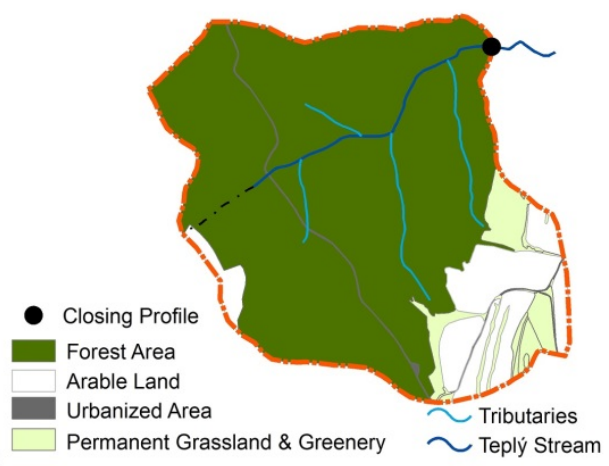

Fig. 2. The Teply Brook catchment and its selected characteristics. 

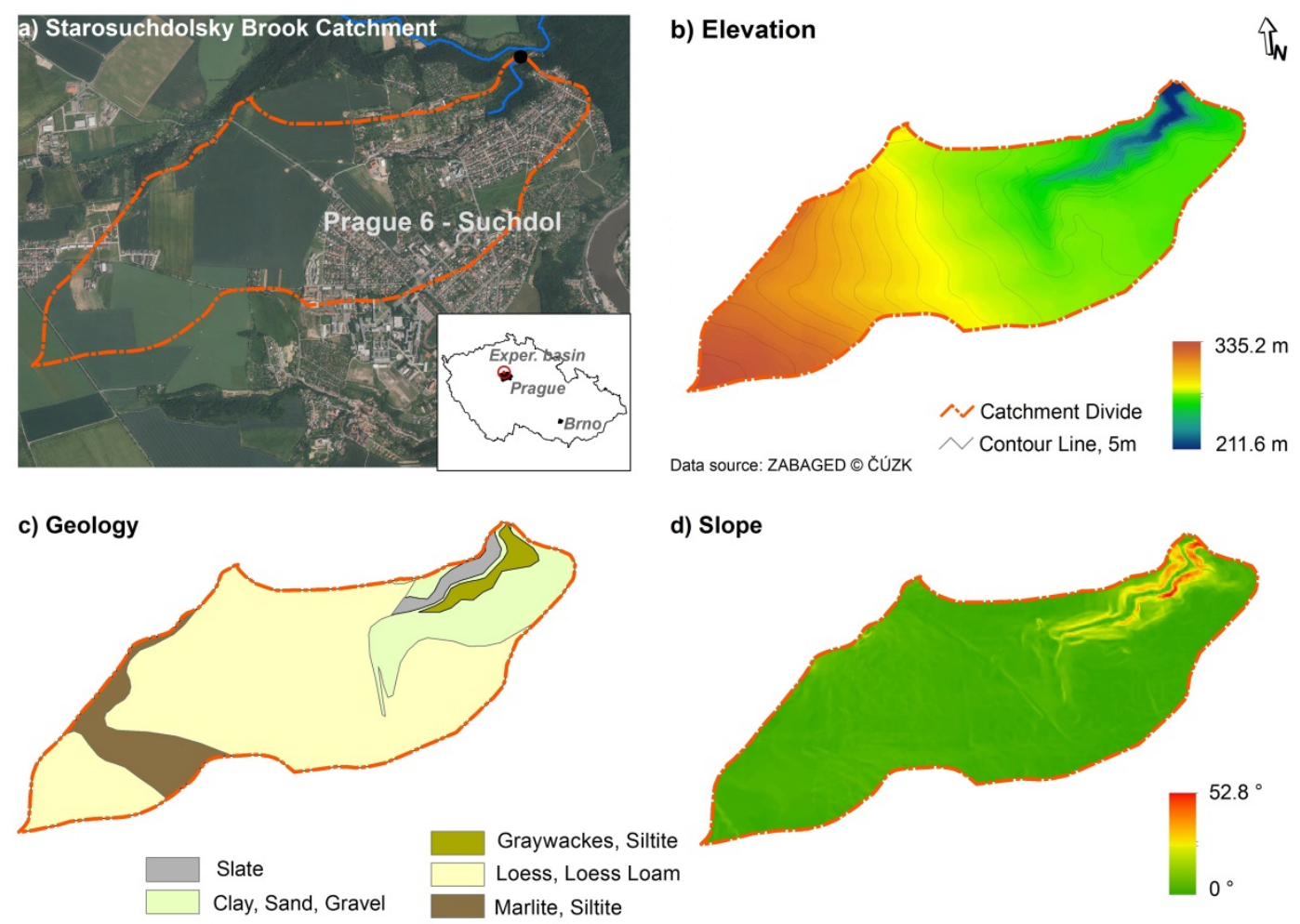

Data source: geoportal geology.cz $\odot$ Czech Geology Survey

e) Soil Types

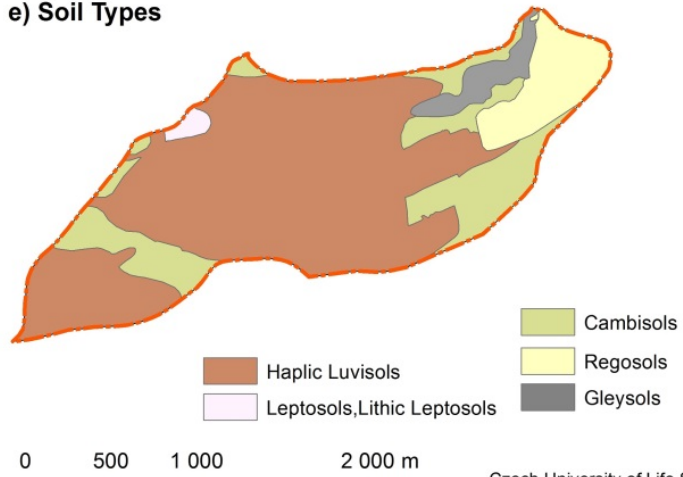

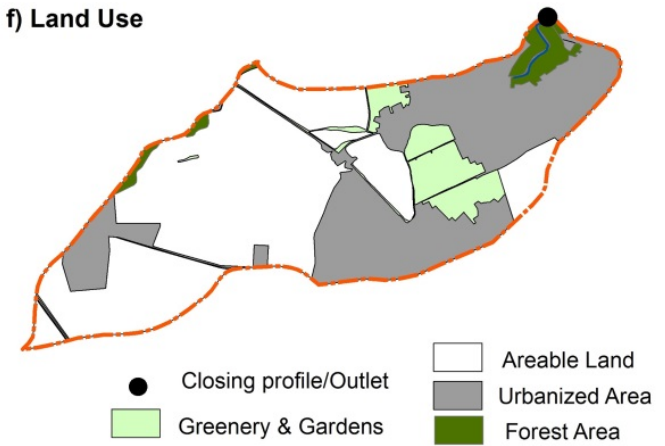

$5001000,2000 \mathrm{~m} \quad$ Czech University of Life Sciencies Prague, 2014

Fig. 3. The Starosuchdolsky Brook catchment and its selected characteristics.

\section{RESULTS}

For each individual day in the Julian calendar years, we have acquired the coefficients $\mathrm{A}, \mathrm{B}, \mathrm{C}$, variables $\mathrm{D}$, resp., then $\tau_{i}$, and $\psi$ for the respective year.

Examples of runoff simulation by the LSM model are shown in Fig. 4. They prove that the model successfully reproduced measured runoff in different hydrometeorological conditions including the periods when evapotranspiration is not the dominant process influencing catchment runoff (e.g. in winter). Fig. 4a represents hot dry day that followed the rainy day. Fig. $4 \mathrm{~b}$ shows catchment discharge that occurred after the rainy day, too but that day remained cold. Fig. 4c shows typical discharge variability during a hot day of longer dry period. Discharge shown in Fig. 4d represents a typical wet and cold winter day.

The goodness of fit between the measured and computed discharge values is excellent. The coefficients of determination (CD) in selected rainless periods never lie outside the scope: $0.95<\mathrm{CD}<1.00$. Matrix inversion (i.e., the least squares method) is the best method of the LSM parameters optimisation.

On the basis of the LSM model coefficients $A, B, C, D, \psi$, and $\tau_{i}$, we have established the yearly ordinates of discharges $\mathrm{Q}$ "consumed" by other hydrologic processes. D is the most important value representing actual evapotranspiration. A, B, (C) are water storages in the soil-zones. The coefficients $\tau_{i}$ are exhaustion times for water storages in the individual soil-water zones and $\psi$ is time between maximum and minimum discharges in the LSM model.

Fig. 5 shows the water amounts consumed by actual evapotranspiration and by hydraulic resistances which would otherwise contribute to catchment runoff.

Fig. 6 shows that calculated daily evapotranspiration was as high as $14 \%$ of catchment daily runoff in the urbanized Starosuchdolsky Brook catchment and $25 \%$ of catchment daily runoff in the forested, less impacted Teply Brook catchment. Higher values for catchment evapotranspiration were calculated in both catchments for period approximately between the beginning of June and mid-July. 


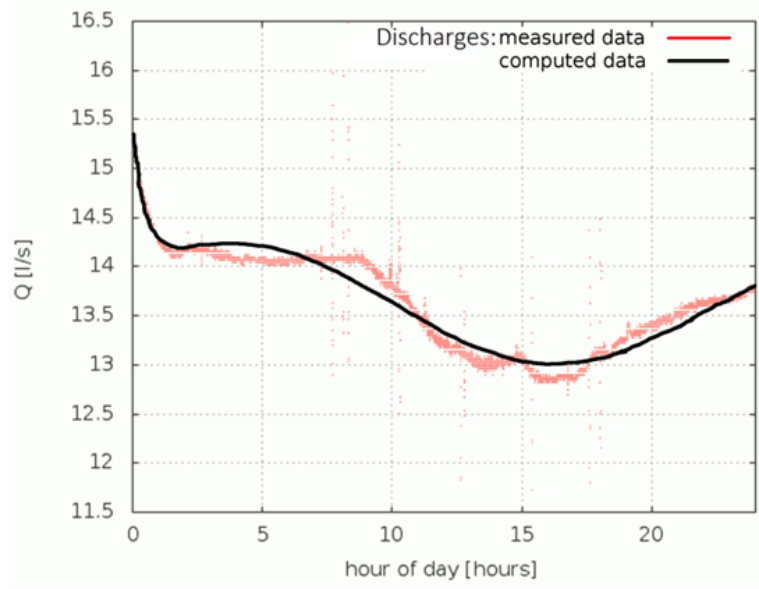

Fig. 4a. Comparison of the measured and computed discharges Q $\left(1 \cdot \mathrm{s}^{-1}\right)$. Starosuchdolsky Brook catchment, 15 June 2011; hot and dry day preceded by the rainy day.

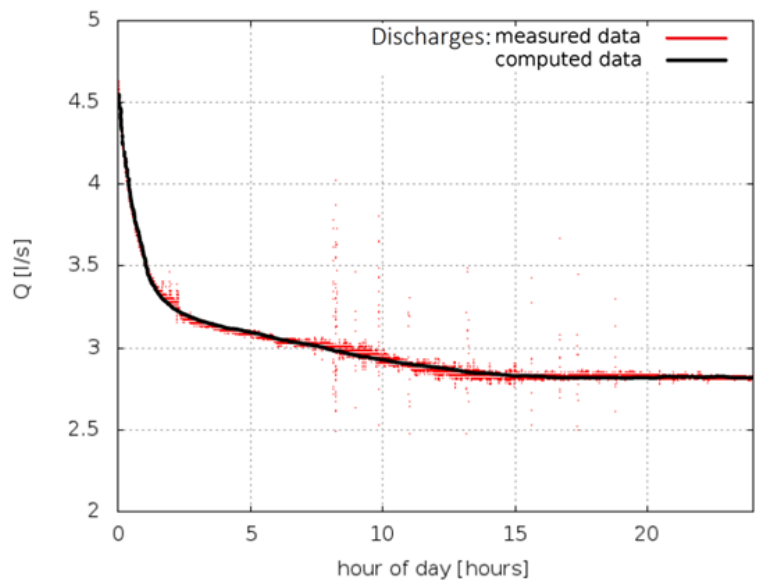

Fig. 4b. Comparison of the measured and computed discharges Q $\left(1 \cdot \mathrm{s}^{-1}\right)$. Starosuchdolsky Brook catchment, 25 April 2012; cold day preceded by the rainy day.

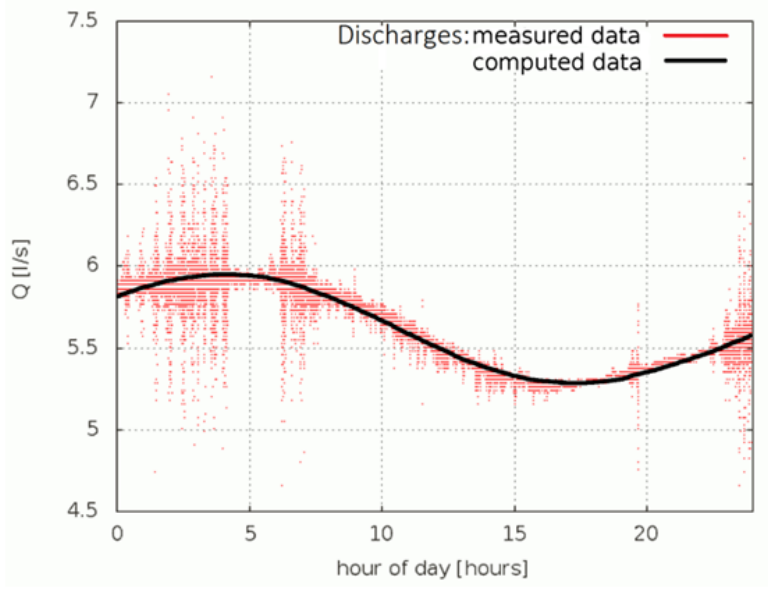

Fig. 4c. Comparison of the measured and computed discharges Q $\left(1 \cdot \mathrm{s}^{-1}\right)$. Teply Brook catchment, 14 May 2004; hot and dry day during a longer dry period.

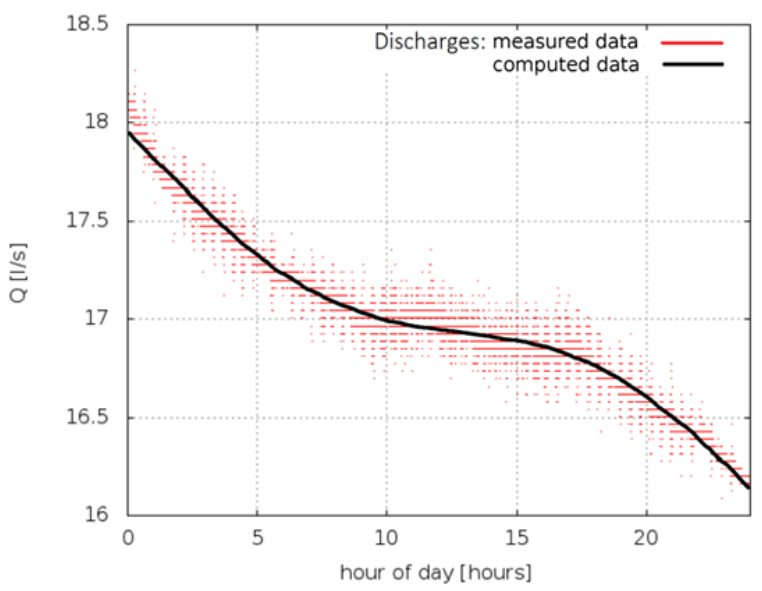

Fig. 4d. Comparison of the measured and computed discharges $\mathrm{Q}\left(1 \cdot \mathrm{s}^{-1}\right)$. Teply Brook catchment, 28 December 2004; typical winter day - wet and cold.

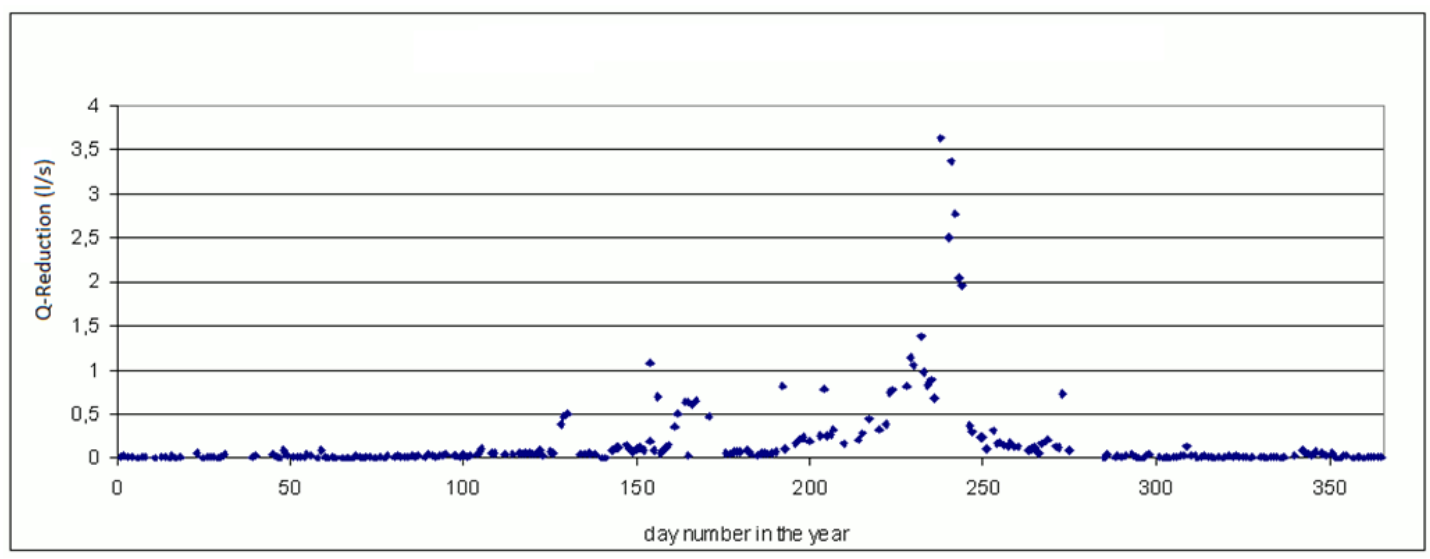

Fig. 5a. Reduction of daily discharge by actual evapotranspiration and hydraulic resistances in the Starosuchdolsky Brook catchment, 2011.

Fig. 7 shows the differences in hydrological responses of the two studied catchments. The time delay between minimum and maximum daily discharges in the Starosuchdolsky Brook catchment show a certain pattern, while in the Teply Brook catchment it is not the case. The time delay in the Starosuchdolsky Brook catchment tends to reach about 20 hours in the warm period of the year (approximately between the midApril to mid-October). Maximum values of the time delay in the Teply Brook catchment also reach about 20 hours. However, the correlations are week in both catchments. Much better correlation could be reached if separated hot and rainless events were analyzed. 


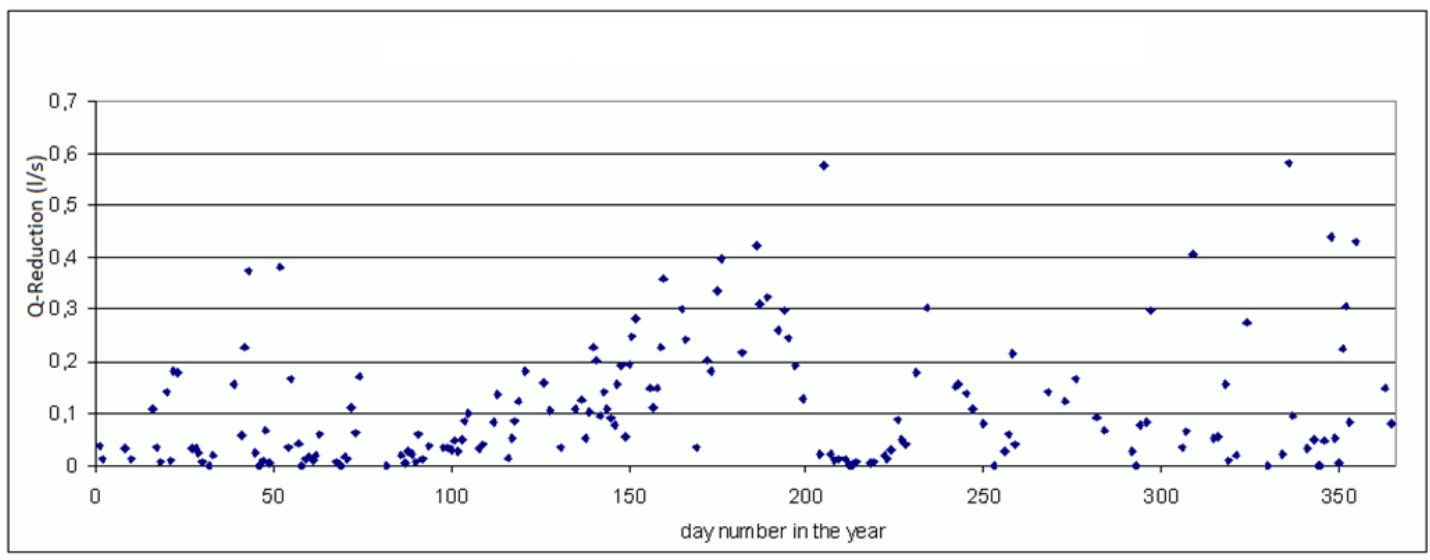

Fig. 5b. Reduction of daily discharge by actual evapotranspiration and hydraulic resistances. Teply Brook catchment, 2004.

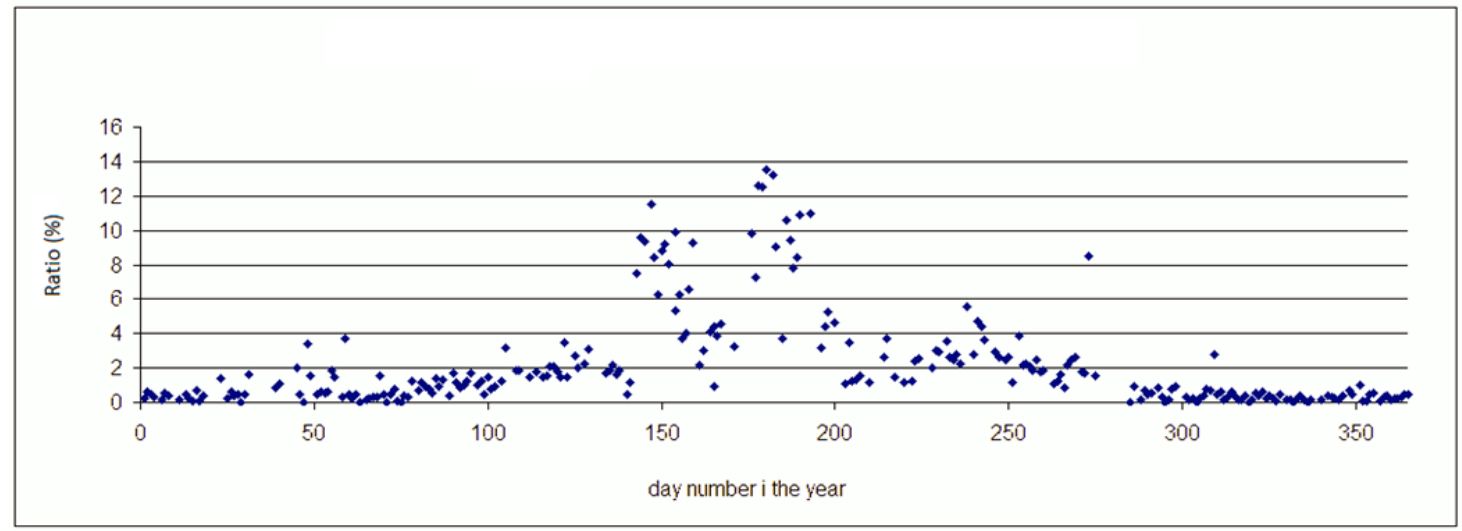

Fig. 6a. The ratio of calculated evapotranspiration to total measured catchment runoff; Starosuchdolsky Brook catchment, 2011.

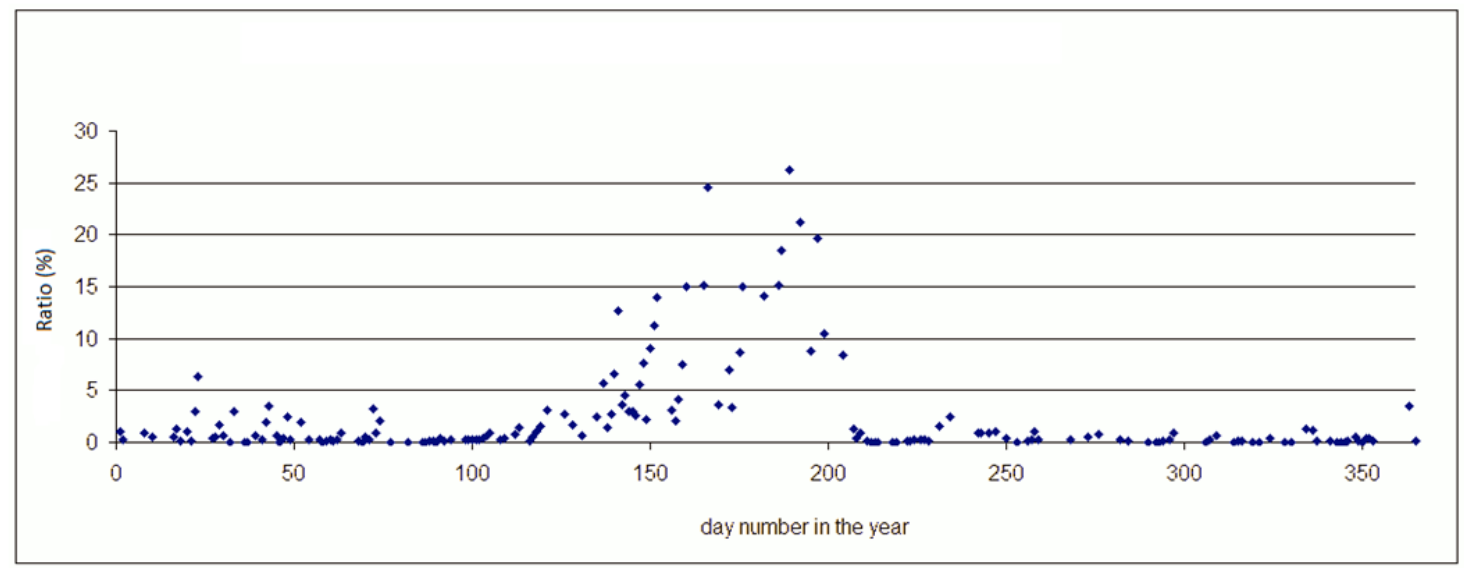

Fig. 6b. The ratio of calculated evapotranspiration to total measured catchment runoff; Teply Brook catchment, 2004.

\section{DISCUSSION}

Discharges, as output of runoff process, can be described as an aggregated component of a water balance equation of the entire catchment (Kirchner, 2009). Ratios of catchment evapotranspiration to catchment runoff and time delays between maximum and minimum streamflows obtained in this study are comparable to those presented e.g. by Bond et al. (2002) and Loheide et al. (2005). Interpretation of the results presented in Figs. 5 and 6 should acknowledge that catchment runoff formation is influenced also by hydraulic resistance which slows down water percolation. Compared to evapotranspiration, the influence of hydraulic resistance is smaller. Our computation indicates that contributions of hydraulic resistance to reduction of catchment runoff reaches up to $15 \%$. The major effect of hydraulic resistance is the delay evapotranspiration influence on catchment discharge. Data on free water evaporation would enhance better understanding of the combined effect of hydraulic resistance and evapotranspiration.

Figs. 5 to 7 show the whole-year results. It is obvious that the influence of evapotranspiration on catchment runoff is dominant in summer during the rainless periods. Further research will be focused on these events. 


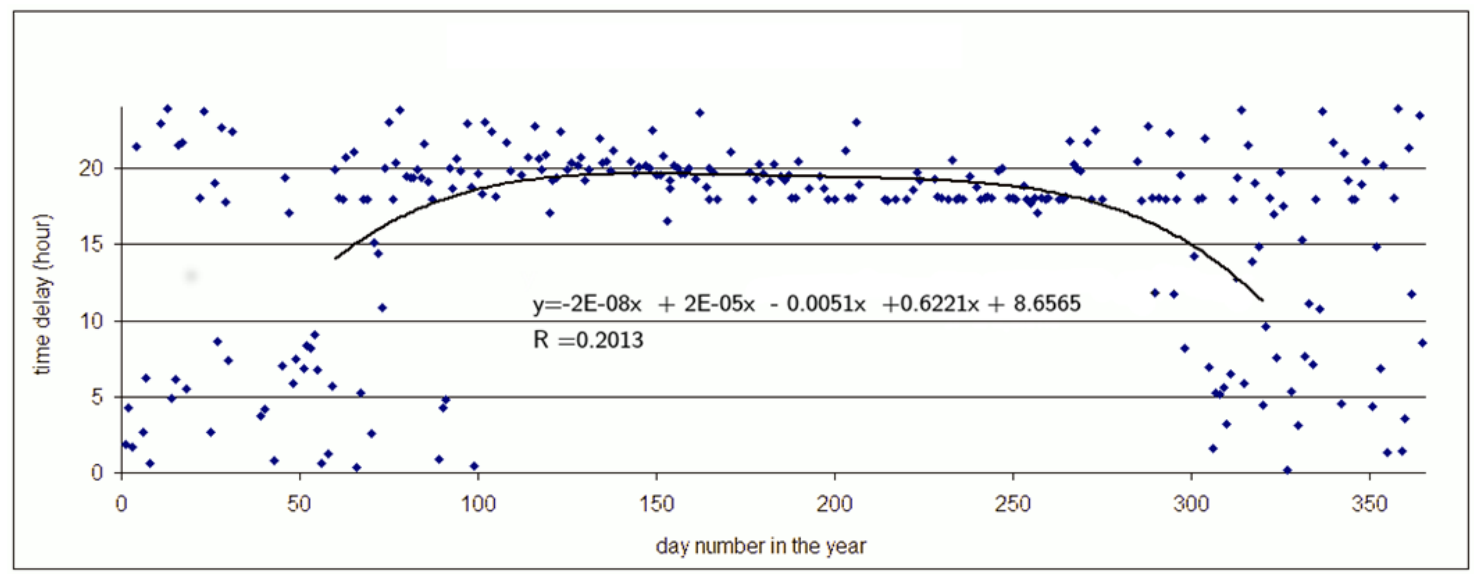

Fig. 7a. Time delay between the daily maximum and minimum streamflow (coefficient $\psi$ ), Starosuchdolsky Brook catchment, 2011.

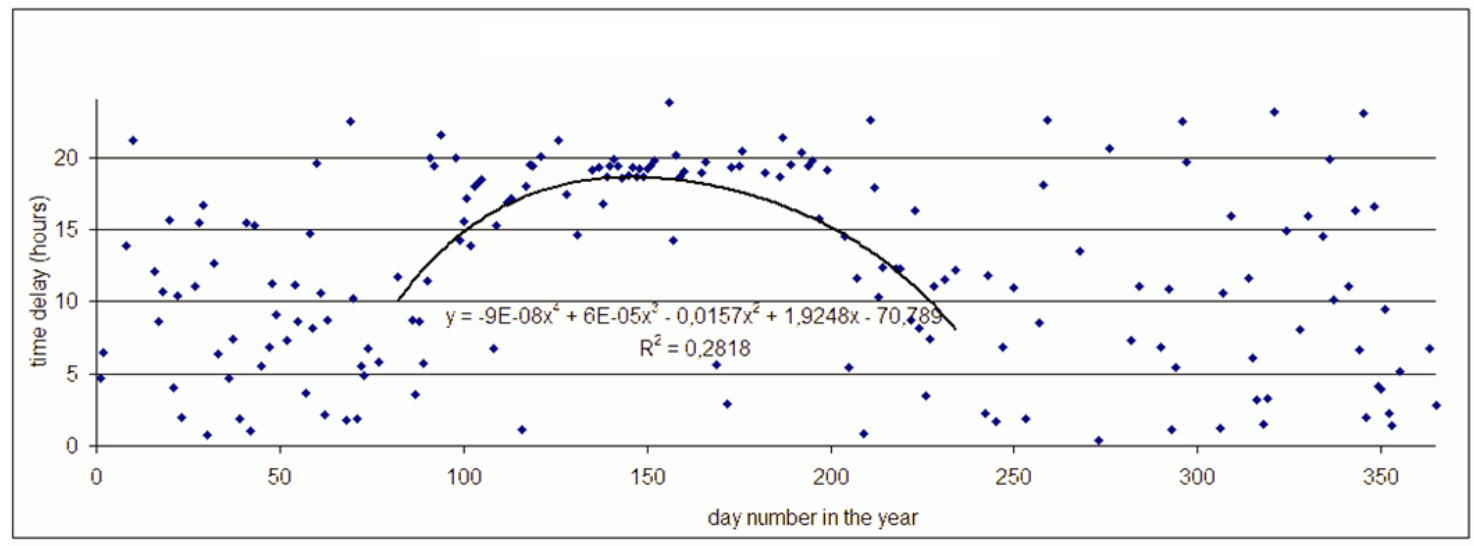

Fig. 7b. Time delay between the daily maximum and minimum streamflow (coefficient $\psi$ ), Teply Brook catchment, 2004.

Both experimental catchments react similarly in the beginning of depletion process when surface and hypodermic water is still available. The overall discharge level after rain has a tendency to diminish fast. The notable difference between the catchments is the fact that the Starosuchdolsky Brook A and B zones are never entirely exhausted. Thus, they always contribute to the catchment discharge, allowing to restructure the threezone model to the two-zone model. Soil moisture content in a soil-zone of riparian vegetation during dry periods usually varies from 0.28 to 0.37 when it is close to the field capacity (i.e., 0.37). This is probably due to fact, that the Starosuchdolsky Brook catchment has a different morphology and the deeper soil-zones than the Teply Brook catchment. The Starosuchdolsky Brook catchment has a downstream catchment much deeper, with wetlands which could explain the difference in the LSM model structures.

Both versions of the LSM models (for two zones and for three zones) are compatible with the threshold idea (Mul et al., 2007), as they can be explained by the combination of thresholds (e.g. borders between soil-zones) with linear storage between them. After calibration, the two versions show a comparable efficiency.

\section{CONCLUSION}

Influence of evapotranspiration on catchment runoff is an interesting and not very often studied hydrological phenomenon. Water use by riparian vegetation is closely linked to streamflow diurnal variability. The LSM model used in this study worked well in both studied catchments. Modification of the model by applying the two- or three- zones versions was necessary to take into account the differences between the catchments. Time delay between minimum and maximum catchment discharges shows a certain pattern in the urbanized Starosuchdolsky Brook catchment. No clear pattern is observed in the forested Teply Brook catchment. Employment of free water evaporation data could improve the methodology of this research in future.

Acknowledgements. This study was supported by the Czech Technological Agency, Project TA02020402 Water regime optimisation to mitigate impacts on hydrological extremes. We thank for its financial support.

\section{REFERENCES}

Bren, L.J., 1997. Effects of slope vegetation removal on the diurnal variations of a small mountain stream. Water Resources Research, 33, 2, 321-331.

Bond, B.J., Jones, J.A., Moore, G., Phillips, N., Post., D., McDonnell, J.J., 2002. The zone of vegetation influence on baseflow revealed by diel patterns of streamflow and vegetation water use in a headwater basin. Hydrol. Process., 16, $1671-1677$.

Burt, T.P., 1979. Diurnal variations in stream discharge and throughflow during a period of low flow. J. Hydrol., 41, 291-301.

Burt, T.P., Pinay, G., Sabater, S., 2010. Riparian zone hydrology and biogeochemistry. IAHS Press series No. 5, Wallingford, UK. 
Dvořáková, Š., Zeman, J., 2010a. Analysis of fluctuation in the stream water level during the dry season in forested areas. Scientia Agriculturae Bohemica, 41, 4, 218-224.

Dvořáková, S., Zeman, J., 2010b. Differential model of summer circulation. In: Trends in Agricultural Engineering, Czech University of Life Sciences, Prague, $4 \mathrm{p}$.

Dvořáková, Š., Kovář, P., Zeman, J., 2012. Implementation of conceptual linear storage model of runoff with diurnal fluctuation in rainless periods. J. Hydrol. Hydromech, 60, 217 226.

Fenicia, F., Savenije, H.H.G., Matgen, P., Pfister, L., 2006. Is the groundwater reservoir linear? Learning from data in hydrological modelling. Hydrol. Earth Syst. Sci., 10, 139-150.

Kirchner, J.W., 2009. Catchment as simple dynamical systems: Catchment characterization, rainfall-runoff modelling and doing hydrology backward. Water Resour. Res., 45, WO02429, 34 p.

Kovář, P., Dvořáková, Š., Pešková, J., Zeman, J., Doležal, F., 2014. Indirect evaluation of the evapotranspiration of a riparian vegetation by the streamflow harmonic analysis. In: Proc. Conf. on Hydrology of small catchment. Vol. 1. Prague, pp. 230-237. (In Czech.)

Larcher, W., 1988. Physiological ecology of plants. Academia, Prague, 361 p. (In Czech.)
Loheide, S.P., Butler, J.J., Gorelick, S.M., 2005. Estimation of groundwater consumption by phreatophytes using diurnal water table fluctuations: A saturated-unsaturated flow assessment. Water Resour. Res., 41, 7, W07030, 14 p.

Mul, M.L., Savenije, H.H.G., Uhlenbrook, S., 2007. Base flow fluctuations from a forested and a cultivated hill slope in northern Tanzania. In: Proc. (CD-Rom) of the 8th WATERNET/WARFSA/GWP-SA Symposium, Lusaka, Zambia, 31 Oct -2 Nov 2007, 9 p.

Szilagyi, J., Gribovszki, Z., Kalicz, P., 2007. Estimation of catchment-scale evapotranspiration from baseflow recession data: Numerical model and practical application results. J. Hydrol., 336, 206-217.

Roznovsky, J., Litschmann, T., Vyskot, I., 2006. Phenological reaction on erratic character of the weather. Brno 22.3.2006, ISBN 80-86690-35-0.

Troxell, H.C., 1936. The diurnal fluctuation in the groundwater and flow of the Santa Ana River and its meaning. Transaction of American Geophysical Union, No. 17, 496-504.

Winsemius, H.C., Savenije, H.H.G., Gerrits, A.M.J., Zapreeva, E.A., Kless, R., 2006. Comparison of two model approaches in the Zambezi river basin with regard to model reliability and identifiability. Hydrol. Earth Syst. Sci., 10, 339-352.

Received 7 February 2014 Accepted 29 September 2014

Note: Colour version of Figures can be found in the web version of this article. 